\title{
Thai Logistics Infrastructure Study of the East West Economic Corridor
}

\author{
J. Wanitwattanakosol and D. Pongpatcharatorntep
}

\begin{abstract}
East-West Economic Corridor (EWEC) is an important corridor for economic cooperation program under the Great Mekong Sub-region. The main objective of this research is to analyze and benchmark the current status and visible short-run prospect of major regional cities. In-depth interview with experts and practitioners, site survey, questionnaires and information based on literature were used to collect information. These cities were selected from three perspectives and evaluated based on the stage of corridor development. This research found that each city was still at an early stage of the corridor development stages.
\end{abstract}

Index Terms-Benchmarking, east-west economic corridor, infrastructure, logistics strategy.

\section{INTRODUCTION}

The development of infrastructure has been an importance part of cooperation under the Great Mekong Sub-region (GMS) economic cooperation program, which began in 1992 [1]. The Lao People's Democratic Republic (Lao PDR), Thailand, Vietnam, Cambodia, the People's Republic of China (PRC) and Myanmar entered into a GMS program for improving opportunities and economic development. Links among GMS countries are strengthened to facilitate trade and to develop logistics for the global competitive market [2]. The East-West Economic Corridor (EWEC) is one of the vital economic corridors according to the Asian Development Bank (ADB)'s perspective.

The EWEC connects through several cities in Vietnam, Lao PDR, Thailand and Myanmar as shown in Fig. 1. Thailand's EWEC network with a total length of about 620 km. comprises Tak, Sukhothai, Phitsanulok, Phetchabun, Khon Kaen, Kalasin and Mukdahan. Logistic infrastructure was also constructed to support the physical linkage within the EWEC.

Banomyong et al. [3] analyzed the status of the EWEC logistics system. It was found that Thailand still requires massive infrastructure development to meet the international standard. However, a study of a detailed provincial logistics infrastructure is still lacking.

This research proposes a logistics performance analysis for the EWEC in Thailand. The rest of this paper is structured as follows. A literature review is briefly provided in next section. Section III presents a research methodology. The

Manuscript received October 1, 2013; revised December 7, 2013. This work was supported in part by The Office of Industrial Economics, Ministry of Industry Thailand.

The authors are with the College of Arts, Media and Technology, Chiang Mai University, Chiang Mai 50200, Thailand (e-mail: jirapat.w@cmu.ac.th, danaitunp@gmail.com). provincial infrastructure perspective is presented and concluded in Section IV and Section V, respectively.

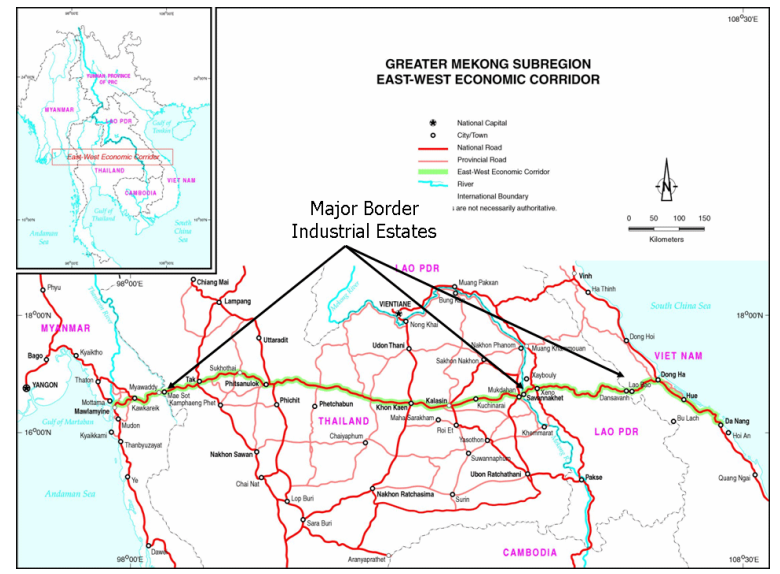

Fig. 1. The GMS east-west economic corridor (EWEC). Source http://www.gmsbizforum.com/show.php?id=132

\section{LITERATURE REVIEW}

\section{A. Role of EWEC in Thailand}

The EWEC has been perceived not only as an economic link of GMS countries, but also as an engine for economic growth and development [4]. As mentioned in the ADB survey, this corridor was designed to employ the geographic feature as border areas, junctions and ports as gateways [5]. The industrial and business sector of Thailand may benefit from a greater variety reduced transport costs by EWEC [6]. The corridor has changed in institution and structure of Thailand.

The eleventh national economic and social development plan (2012-2016) regards the country's infrastructure and logistics systems [7]. Infrastructure and multimodal transportation management systems should be developed for both domestic and international uses. Laws and regulations should be amended for making trade more efficient by using the National Single Window system, distribution center and cross-border trade.

Effective distribution systems will reduce the overall logistics cost and support regional economic cooperation. The eleventh plan focuses on the railway system by improving the present railway system. High speed railways and dual-track rail lines along major routes are planned to link major regional cities and GMS countries.

\section{B. Logistics Related Dimensions}

Banomyong [2] proposed an evaluation model to determine the overall capability of the macro logistics system within the scope of the geographical area. The four 
logistics-related dimensions model comprised (1) shippers, traders and consignees; (2) public, private sector logistics and transport service providers; (3) provincial and national institutions, policies and rules; (4) transport and communication infrastructure.

This model was employed to evaluate the logistics development of GMS countries [8]. It was found that each GMS country is still at an early stage. However, the GMS infrastructure had some gaps to bridge, especially for the border facilities.

\section{ReSEARCh Methodology}

In-depth interview with experts and practitioners, site survey, questionnaires and information based on literature are used to collect information. Major regional cities are selected from three perspectives which comprise (1) the major cities which are important to connect with other corridors in GMS; (2) the major cities which are related with the eleventh national economic and social development plan; (3) the major cities which has a potential based on the four logistics-related dimensions.

After a selected procedure, selected cities are evaluated based on the stage of corridor development [9] as depicted in Table I. All stage is evaluated with five strategies for logistics system development of the tenth national economic and social development plan [10]. Moreover, each strategy has four key performance indicators (KPIs). Table II- Table VI display KPIs used in this study. Finally, this framework is used to assess the existing development of each major city.

TABLE I: CORRIDOR DEVELOPMENT STAGES

\begin{tabular}{|c|c|c|}
\hline Stage & $\begin{array}{l}\text { Type of } \\
\text { Corridor }\end{array}$ & Definition \\
\hline 1 & Transport & Corridor that physically links an area or region. \\
\hline 2 & Multimodal & $\begin{array}{l}\text { Corridor that physically links an area or region } \\
\text { through the integration of various modes of } \\
\text { transport. }\end{array}$ \\
\hline 3 & Logistics & $\begin{array}{l}\text { Corridor that not only physically links an area } \\
\text { or a region but also harmonizes the corridor } \\
\text { institutional framework to facilitate the efficient } \\
\text { movement and storage of freight, people, and } \\
\text { related information. }\end{array}$ \\
\hline 4 & Economic & $\begin{array}{l}\text { Corridor that is able to attract investment and } \\
\text { generate economic activities along the less } \\
\text { developed area or region; physical links and } \\
\text { logistics facilitation must first be in place. }\end{array}$ \\
\hline
\end{tabular}

Source: Banomyong et al. (2008) [2]

TABLE II: BUSINESS LOGISTICS IMPROVEMENT

\begin{tabular}{cl}
\hline \hline KPI & \multicolumn{1}{c}{ Definition } \\
\hline 1 & $\begin{array}{l}\text { Lower logistics costs. } \\
\text { Greater customer responsiveness (convenient, fast and } \\
\text { precise response to customer's needs). } \\
\text { Increased number of logistics service providers or increased } \\
\text { service values. } \\
4\end{array}$ \\
& $\begin{array}{l}\text { Lower transportation costs throughout the supply chain and } \\
\text { increase the number of business associations collaborating in } \\
\text { the development of logistics services. }\end{array}$ \\
\hline \hline
\end{tabular}

\section{RESUlT AND DisCUSSION}

This research was carried out in provinces along the
EWEC. Based on the empirical evidence collected on seven provinces and literature, it was found that Tak, Phitsanulok, Khon Kaen and Mukdahan were major regional cities by considering three perspectives as presented Table VII. A following assessment was briefly described below.

TABLE III: TRANSPORT AND LOGISTICS NETWORK OPTIMIZATION

\begin{tabular}{cl} 
KPI & \multicolumn{1}{c}{ Definition } \\
\hline 1 & $\begin{array}{l}\text { Reduce transport times on main trade routes. } \\
\text { Companies enjoying lower logistics costs relative to sales } \\
\text { revenues. }\end{array}$ \\
3 & $\begin{array}{l}\text { A railway system linking ports on the western coast with } \\
\text { regional transport routes, major trading centers and the major } \\
\text { trading cities. } \\
4\end{array}$ \\
& $\begin{array}{l}\text { Lower investment costs of the private sector or private } \\
\text { entities investing in the development of logistics/distribution } \\
\text { centers. }\end{array}$ \\
\hline \hline
\end{tabular}

TABLE IV: LOGISTICS SERVICE INTERNATIONALIZATION

\begin{tabular}{cl}
\hline \hline KPI & \multicolumn{1}{c}{ Definition } \\
\hline 1 & Increasing the numbers of logistics service providers. \\
2 & Increasing co-operation among businesses. \\
3 & Increasing the sales revenues of logistics-service providers \\
& whose majority shareholders are Thai. \\
4 & Increasing the number of specific service providers. \\
\hline \hline
\end{tabular}

TABLE V: TRADE FACILITATION ENHANCEMENT

\begin{tabular}{cl}
\hline \hline KPI & \multicolumn{1}{c}{ Definition } \\
\hline 1 & Less processing time for import or export documentation. \\
2 & Reduced time for transporting import and export goods or \\
& transferring goods between ships. \\
3 & Lower distribution costs for Thai exporters. \\
4 & Setting up standardization with regard to data sharing. \\
\hline \hline
\end{tabular}

TABLE VI: CAPACITY BUILDING

\begin{tabular}{cl}
\hline \hline KPI & \multicolumn{1}{c}{ Definition } \\
\hline 1 & $\begin{array}{l}\text { To train logistics personnel in the industrial sector, especially } \\
\text { in SMEs, and personnel in the logistics-service industry. }\end{array}$ \\
2 & $\begin{array}{l}\text { Introduce clear standards for logistics professionals and } \\
\text { logistics labor skills. }\end{array}$ \\
3 & $\begin{array}{l}\text { Establishment of a data system which manages the country's } \\
\text { logistics system linked in a network manner at both macro } \\
\text { and micro levels. } \\
\text { The national logistics development committee is appointed } \\
\text { and functioning. }\end{array}$ \\
\hline \hline
\end{tabular}

TABLE VII: THAI MAJOR CITIES ALONG EWEC

\begin{tabular}{|l|l|}
\hline \multicolumn{1}{|c|}{ Perspective } & \multicolumn{1}{|c|}{ Potential city } \\
\hline $\begin{array}{l}\text { Important to connect with other } \\
\text { corridors in GMS }\end{array}$ & $\begin{array}{l}\text { Tak, Phitsanulok and } \\
\text { Mukdahan }\end{array}$ \\
\hline $\begin{array}{l}\text { Related with the eleventh national } \\
\text { economic and social development } \\
\text { plan }\end{array}$ & Phitsanulok and Khon Kaen \\
\hline $\begin{array}{l}\text { A potential based on the four } \\
\text { logistics-related dimensions }\end{array}$ & Phitsanulok and Khon Kaen \\
\hline
\end{tabular}

\section{A. Mukdahan}

Mukdahan has played an important role as a major trading center on the western coast of Thailand. Mukdahan connects Sawanakhet (Lao PDR, being landlocked) on the $2^{\text {nd }}$ Lao-Thai friendship bridge between funded by a Japan Bank for International Cooperation. Moreover, Mukdahan is a border gateway to the South China Sea at Nanning from GMS Cross-Border Transport Agreement.

The Customs department has used modern information 
technology in managing logistics including with prepared facilitations to be the National Single Window system. It also reduced time for transporting import and export goods by paying fee at any currency.

Tourism development in GMS economic corridors has a number of challenges to relatively established tourism destinations. However, Mukdahan has been identified not only as a flagship to travel in the Northeast of Thailand, but also a convenient access to Hue and Danang in Vietnam.

\section{B. Khon Kaen}

Khon Kaen had the highest potential level for economic development on the four logistics-related dimensions perspective. Khon Kaen was an important part to connect domestic and regional rail transport. Infrastructure and Multimodal transportation management system was prepared to establish economic links with GMS countries.

To promote the setting up of distribution and logistics center, Khon Kaen has developed a strategic plan which is called "BIRDs" (B = Bus rapid transit, I = International airport, $\mathrm{R}=$ Railway system, $\mathrm{D}=$ Distribution center and $\mathrm{s}=$ Sustainability). Khon Kaen is the regional center of the production and service sectors.

\section{Phitsanulok}

Phitsanulok was enumerated as a junction of North-South Economic Corridor (NSEC). Commodities produced at cities along the EWEC can be distributed to cities along the NSEC [11]. This province is an important and historic city in lower Northern region of Thailand.

Phitsanulok had a great potential on the four logistics-related dimensions perspective, especially for transport and communication infrastructure. The city is on the intersection of several major highways linked Northern, Northeastern and Central region of Thailand.

\section{Tak}

The EWEC is a land bridge linking the Indian Ocean with the Pacific Ocean. This corridor passes through the border crossing in Tak. Tak has increased economic connectivity along border area and special economic zone in Myanmar.

Tak was a great place on internationally trading and national commercializing. Tak has planned to support Myanmar as a center for commercial, entertainment, educational institutions and medical services.

Each type of corridor was determined via five strategies for logistics system development. The benchmarking was then made. Fig. 2 summarizes the corridor development benchmarking of each stage.

All strategies have equally four scores based on KPI. Each major regional city was assessed for each KPI based on an in-depth understanding of the "AS-IS" situation and visible short-run prospect. It should be noted that the lowest score of strategies was used to determine a current corridor status of each city. For example, almost strategies except strategy five were rated as a score of 3 and strategy five was rated as a score of 1 . This example was only judged as the transport corridor.

Mukdahan solely focused private sector development such as increased number of manufactured and agricultural enterprises. Thus, a number of private logistics service providers were not only expanded to support increased business activities but also logistics investment costs were lower for the development of logistics. In addition, co-operation among businesses was enlarged.

\section{The corridor development benchmarking}

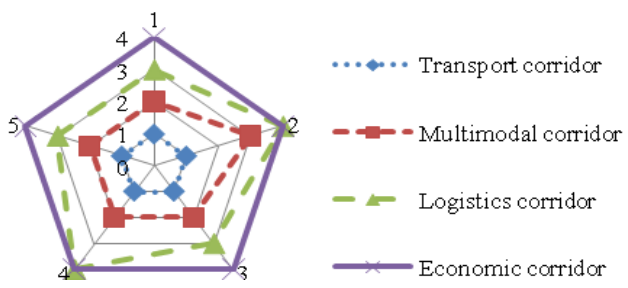

Fig. 2. The corridor development benchmarking via five strategies.

Although the government sector has supported to train logistics personnel and encourage the application of information technology for reducing import or export documentation processed time, but road, railways and air transport were not well prepared for the ASEAN Economic Community.

However, Thailand has a proactive policy for Mukdahan by investing in dual-track rail lines and altering considerably close distance military airport, which locates at Loeng Nok Tha district, Yasothon, to commercial airport. It can be summarized that Mukdahan was still at the transport corridor and should be at the multimodal corridor in the near future as depicted in Fig. 3 and Table VIII, respectively.

\section{The corridor development benchmarking}

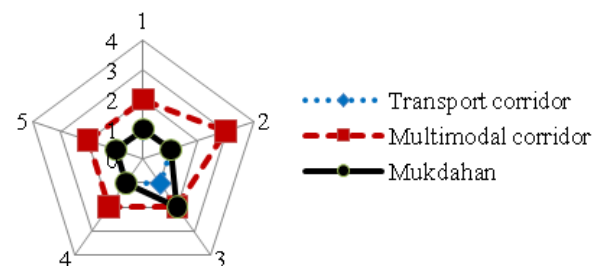

Fig. 3. The corridor development of Mukdahan.

TABLE VIII: THE LOGISTICS ASSESSMENT OF MUKDAHAN

\begin{tabular}{|c|c|}
\hline Strategy for logistics system development & Level \\
\hline Business logistics improvement & $1(3)$ \\
\hline Transport and logistics network optimization & $1(4)$ \\
\hline Logistics service internationalization & $2(1,2)$ \\
\hline Trade facilitation enhancement & $1(1)$ \\
\hline capacity building & $1(1)$ \\
\hline Overall assessment & Transport corridor \\
\hline
\end{tabular}

Where the number in parenthesis is achieved KPIs?

Khon Kaen was the promising major regional city along the EWEC. Nevertheless information system, which is an important factor, should be developed for a sustainable logistics strategy mechanism. The number of specific service providers should be increased for decreasing delivery times and responding customer requisitions.

The multimodal corridor was represented in this research and the logistics corridor should be set in visible short-run 
prospect. Table IX and Fig. 4 exhibit the Khon Kaen benchmark study.

TABLE IX: THE LOGISTICS ASSESSMENT OF KHON KAEN

\begin{tabular}{|c|c|}
\hline Strategy for logistics system development & Level \\
\hline Business logistics improvement & $3(1,2,3)$ \\
\hline Transport and logistics network optimization & $3(2,3,4)$ \\
\hline Logistics service internationalization & $2(1,2)$ \\
\hline Trade facilitation enhancement & $2(1,2)$ \\
\hline capacity building & $2(1,2)$ \\
\hline Overall assessment & Multimodal corridor \\
\hline
\end{tabular}

The corridor development benchmarking

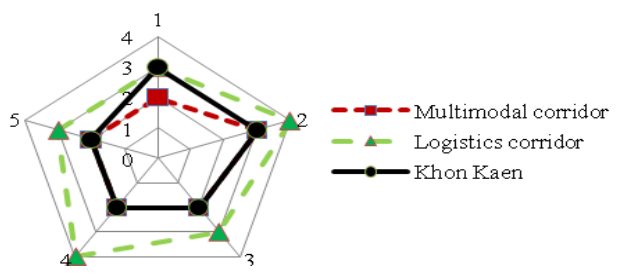

Fig. 4. The corridor development of Khon Kaen.

Strategy two (transport and logistics network optimization) and strategy four (trade facilitation enhancement) were distinguished points from continuous participant between public and private sectors in Phitsanulok. This city was the junction of main economic corridors and integrated multimodal transportation management system.

Nonetheless, this city should encourage in strategy one, three and five, respectively. Hence, it was at the same stage with that of Khon Kaen as shown in Table X and Fig. 5.

TABLE X: THE LOGISTICS ASSESSMENT OF PHITSANULOK

\begin{tabular}{|c|c|}
\hline Strategy for logistics system development & Level \\
\hline Business logistics improvement & $2(1,4)$ \\
\hline Transport and logistics network optimization & $3(1,2,3)$ \\
\hline Logistics service internationalization & $2(1,2)$ \\
\hline Trade facilitation enhancement & $3(1,2,4)$ \\
\hline capacity building & $2(1,3)$ \\
\hline Overall assessment & Multimodal corridor \\
\hline
\end{tabular}

The corridor development benchmarking

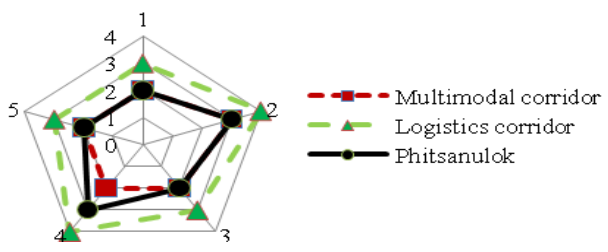

Fig. 5. The corridor development of Phitsanulok.

Contrary to business logistics improvement and logistics service internationalization were the greatest developments; capacity building was the weakest link of Tak. Thus information system, transportation system and logistics center should be stimulated for reducing time and cost to delivery in domestic and international trade.

The transport corridor was the corridor development stage for Tak. In the near future, this place should be developed to the logistics corridor as displayed in Table XI and Fig. 6.

TABLE XI: THE LOGISTICS ASSESSMENT OF TAK

\begin{tabular}{|c|c|}
\hline Strategy for logistics system development & Level \\
\hline Business logistics improvement & 4 \\
\hline Transport and logistics network optimization & $2(2,4)$ \\
\hline Logistics service internationalization & 4 \\
\hline Trade facilitation enhancement & $2(1,3)$ \\
\hline capacity building & $1(1)$ \\
\hline Overall assessment & Transport corridor \\
\hline
\end{tabular}

\section{The corridor development benchmarking}

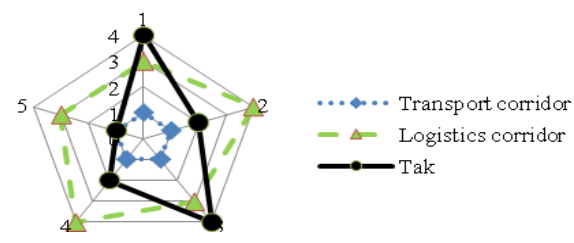

Fig. 6. The corridor development of Tak.

\section{CONCLUSION}

This research has provided an overview of the logistics capability of Thai major regional cities in the EWEC. Each city is still at an early stage of the corridor development stages. However, Mukdahan could be the logistics corridor and the rest could be the economic corridor in the foreseeable long-run prospect.

\section{REFERENCES}

[1] A. Strutt, S. Stone, and P. Minor, "Trade facilitation in the Great Mekong Subregion: Impact of reducing the time to trade," Journal of Greater Mekong Subregion Development Studies, vol. 4, pp. 1-20, December 2008

[2] R. Banomyong, "Logistics development in the north-south economic corridor of the Great Mekong Subregion," Journal of Greater Mekong Subregion Development Studies, vol. 4, pp. 43-58, December 2008.

[3] R. Banomyong, A. Sopadang, and S. Ramingwong, "Logistics benchmark study of the east west economic corridor," Business Management Quarterly Review, vol. 1, no. 2, pp. 1-13, 2010.

[4] Y. Apichatvullop and P. Phucharoensilp, "The east-west economic corridor project in Thailand: perceived meanings and expectations," in Mekong Institute Research Working Paper Series, Khon Kaen: The Research and Learning Resource Center of the Mekong Institute, 2007, no. 4.

[5] ADB, "Preinvesment study for the Great Mekong Subregion east-west economic corridor," in Integrative Report, Manila: ADB, 2001, vol. 1.

[6] P. Brahmawong and R. Sukharomana, "East-west economic corridor and southern economic corridor of Great Mekong Subregion: Who gains and who loss?" Economics and Public Policy, vol. 3, no. 6, pp. 131-155.

[7] The Eleventh National Economic and Social Development Plan, National Economic and Social Development Board, Office of the Prime Minister, Bangkok, Thailand, 2012.

[8] R. Banomyong, "Benchmarking economic corridors logistics performance: a GMS border crossing observation," World Custom Journal, vol. 4, no.1, pp. 29-38, 2010.

[9] R. Banomyong, P. Cook, and P. Kent, "Formulating regional logistics development policy: The case of ASEAN," International Journal of Logistics Research and Application, vol. 11, no. 5, pp. 359-379, 2008.

[10] Thailand's Logistics Development Strategy (2007-2011), National Economic and Social Development Board, Office of the Prime Minister, Bangkok, Thailand, 2007. 
[11] M. Ishida, "GMS economic cooperation and its impact on CLMY development," in Development Strategy for CLMV in the Age of Economic Integration, C. Sotharith, Ed, Chiba: IDE-JETRO, 2008, pp. $115-140$.

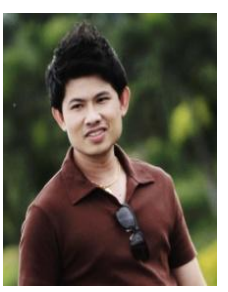

Jirapat Wanitwattanakosol received his bachelor degree of industrial engineering from Chiang Mai University, Thailand in 2002. He holds master of engineering, from Department of Industrial Engineering, Chulalongkorn University, Thailand since 2007. He also holds Ph.D. in industrial engineering from Department of Industrial Engineering, Chiang Mai University, Thailand since 2013. He is a Chairperson of B.A. program in Modern Management and Information Technology, College of Arts, Media and Technology, Chiang Mai University. He has worked Chiang Mai University since 2012. He was a lecturer at Department of Industrial Engineering, Faculty of Engineering,Rajamangala University of Technology Lanna
Chiang Rai, Thailand in 2010-2011. His research interests include lean manufacturing, supply chain and logistics management. Dr. Wanitwattanakosol got the Royal Golden Jubilee Ph.D Program Outstanding Research Awards from The Thailand Research Fund.

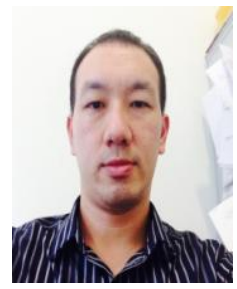

Danaitun Pongpatcharatorntep received his bachelor degree of industrial engineering from Chiang Mai University, Thailand in 1997. He holds master of science in economics, from School of Economics, Kasetsart University, Thailand since 2001. Now, he is a Ph.D candidate in managemen science and engineering from school of management Zhejiang University, China PR. He is a lecturer of knowledge management program, College of Arts, Media and Technology, Chiang Mai University. He has worked Chiang Mai University since 2006. He was a lecturer at School of Economics, Payap University, Chiang Mai, Thailand in 2002-2006. And he was a production Engineer in Michelin manufacturing Thailand in 1997-2001. His research interests include international logistics and supply chain 